OPEN ACCESS

Edited by: Alison Buchan,

University of Tennessee, Knoxville,

United States

Reviewed by:

Zhanfei Liu,

University of Texas at Austin,

United States

Xiao-Hua Zhang,

Ocean University of China, China

${ }^{*}$ Correspondence:

Birthe Zäncker

birzan@mba.ac.uk

Specialty section:

This article was submitted to

Aquatic Microbiology,

a section of the journal

Frontiers in Microbiology

Received: 23 July 2018

Accepted: 23 October 2018

Published: 15 November 2018

Citation:

Zäncker B, Cunliffe M and Engel A

(2018) Bacterial Community

Composition in the Sea Surface

Microlayer Off the Peruvian Coast.

Front. Microbiol. 9:2699.

doi: 10.3389/fmicb.2018.02699

\section{Bacterial Community Composition in the Sea Surface Microlayer Off the Peruvian Coast}

\author{
Birthe Zäncker ${ }^{1 *}$, Michael Cunliffe ${ }^{2,3}$ and Anja Engel ${ }^{1}$ \\ ${ }^{1}$ GEOMAR - Helmholtz Centre for Ocean Research Kiel, Kiel, Germany, ${ }^{2}$ Marine Biological Association of the \\ United Kingdom, Plymouth, United Kingdom, ${ }^{3}$ Marine Biology and Ecology Research Centre, School of Biological \\ and Marine Sciences, Plymouth University, Plymouth, United Kingdom
}

The sea surface microlayer (SML) is located at the air-sea interface, with microorganisms and organic matter in the SML influencing air-sea exchange processes. Yet understanding of the SML bacterial (bacterioneuston) community composition and assembly remains limited. Availability of organic matter, UV radiation and wind speed have previously been suggested to influence the community composition of bacterioneuston. Another mechanism potentially controlling bacterioneuston dynamics is bacterioplankton attached to gel-like particles that ascend through the water column into the SML. We analyzed the bacterial community composition, Transparent Exopolymer Particles (TEP) abundance and nutrient concentrations in the surface waters of the Peruvian upwelling region. The bacterioneuston and bacterioplankton communities were similar, suggesting a close spatial coupling. Four Bacteroidetes families were significantly enriched in the SML, two of them, the Flavobacteriaceae and Cryomorphaceae, were found to comprise the majority of SML-enriched operational taxonomic units (OTUs). The enrichment of these families was controlled by a variety of environmental factors. The SML-enriched bacterial families were negatively correlated with water temperature and wind speed in the SML and positively correlated with nutrient concentrations, salinity and TEP in the underlying water (ULW). The correlations with nutrient concentrations and salinity suggest that the enriched bacterial families were more abundant at the upwelling stations.

Keywords: microbial ecology, sea surface microlayer, SML, bacteria, cruise SO243, RV Sonne, peruvian upwelling region, transparent exopolymer particles

\section{INTRODUCTION}

The sea surface microlayer (SML) constitutes the uppermost layer of the ocean, only 1$1000 \mu \mathrm{m}$ thick, with unique chemical and biological properties that distinguish it from the underlying water (ULW) (Zhang et al., 2003; Liss and Duce, 2005). Due to the location at the air-sea interface, the SML can influence exchange processes across this boundary 
layer, such as air-sea gas exchange and the formation of sea spray aerosols (Liss and Duce, 2005; Wurl and Holmes, 2008; Aller et al., 2017; Engel et al., 2017).

The term 'neuston' describes the organisms in the SML and was first suggested by Naumann (1917). As in other marine ecosystems, bacterioneuston communities have important roles in SML functioning (Cunliffe et al., 2011). Bacterioneuston community composition of the SML has been analyzed and compared to the underlying water in different habitats with varying results, and has primarily focused on coastal waters and shelf seas, with limited study of the open ocean (Agogué et al., 2005a; Franklin et al., 2005; Cunliffe et al., 2009c). In the North Sea, a distinct bacterial community was found in the SML with Vibrio spp. and Pseudoalteromonas spp. dominating the bacterioneuston (Franklin et al., 2005). During an artificially induced phytoplankton bloom in a fjord mesocosm experiment, the most dominant denaturing gradient gel electrophoresis (DGGE) bands of the bacterioneuston consisted of two bacterial families: Flavobacteriaceae and Alteromonadaceae (Cunliffe et al., 2009c). Other studies have however, found little or no differences in the bacterial community composition of the SML and the ULW (Agogué et al., 2005a; Obernosterer et al., 2008). Difficulties in direct comparisons between studies can arise because of the different methods used to sample the SML, which result in varied sampling depths (Agogué et al., 2004; Cunliffe et al., 2009a, 2011).

Even less is known about the community control mechanisms in the SML and how the bacterial community assembles at the airsea interface. The bacterioneuston community could be altered by differing wind conditions and radiation levels (Agogué et al., 2005b; Joux et al., 2006; Stolle et al., 2011; Rahlff et al., 2017), with high wind speeds inhibiting the formation of a distinct bacterioneuston community (Stolle et al., 2011; Rahlff et al., 2017). Wind speed and radiation levels refer to external controls, however, bacterioneuston community composition might also be influenced by internal factors such as nutrient availability and organic matter (OM) produced either in the SML or in the ULW (Azam et al., 1993; Judd et al., 2006; Nakajima et al., 2013).

One of the principal OM components consistently enriched in the SML are Transparent Exopolymer Particles (TEP) (Cunliffe et al., 2009b; Wurl et al., 2011; Engel and Galgani, 2016), which are rich in carbohydrates and form by the aggregation of dissolved precursors excreted by phytoplankton in the euphotic zone (Chin et al., 1998; Passow, 2000; Passow et al., 2001; Engel et al., 2004). Higher TEP formation rates in the SML, facilitated through wind shear and dilation of the surface water, have been proposed as one explanation for the observed enrichment in TEP (Wurl et al., 2011; Sun et al., 2018). Also, due to their natural positive buoyancy, when not ballasted by other particles sticking to them, TEP ascend through the water column and ultimately end up at the SML (Azetsu-Scott and Passow, 2004). A second possible pathway of TEP from the water column to the SML is by bubble scavenging (Zhou et al., 1998).

Next to rising bubbles, another potential transport mechanism for bacteria from the ULW to the SML could be ascending particles (Agogué et al., 2005a; Joux et al., 2006) or more specifically TEP (Azetsu-Scott and Passow, 2004). Bacteria readily attach to TEP in the water column (Schuster and Herndl, 1995; Mari and Kiorboe, 1996; Busch et al., 2017). TEP can serve as microbial hotspots and can be used directly as a substrate for bacterial degradation (Passow, 2002; Meiners et al., 2008; Taylor and Cunliffe, 2017), and as grazing protection for attached bacteria, e.g., by acting as an alternate food source for zooplankton (Malej and Harris, 1993; Passow and Alldredge, 1999; Dutz et al., 2005). TEP have also been suggested to serve as light protection for microorganisms in environments with high irradiation (Ortega-Retuerta et al., 2009).

This study focuses on understanding the bacterioneuston community composition as well as possible community control mechanisms. Therefore, we analyzed the composition of the bacterial community in the SML and ULW as well as various abiotic factors in addition to nutrients and TEP concentrations during a cruise in the Peruvian upwelling region.

\section{MATERIALS AND METHODS}

\section{Sampling}

Samples were collected during the SO243 cruise to the Peruvian upwelling region onboard the RV Sonne from the 4 th to the 22 nd of October 2015 (Figure 1A), with 11 stations sampled between $0^{\circ} \mathrm{S}$ and $15.7^{\circ} \mathrm{S}$ as well as $85.5^{\circ} \mathrm{W}$ and $75.3^{\circ} \mathrm{W}$ (Figure 1B). At each station, samples were collected from two depths: surface microlayer (SML) and underlying water (ULW) at $20 \mathrm{~cm}$, except at station 1 where an ULW sample was taken at $10 \mathrm{~cm}$. SML sampling was conducted using a glass plate sampler from a zodiac (Harvey, 1966; Cunliffe and Wurl, 2014). The $50 \times 26 \mathrm{~cm}$ silicate glass plate had an effective sampling surface area of $2600 \mathrm{~cm}^{2}$ considering both sides. For sampling, the zodiac was located app. 0.5 nautical miles into the wind direction away from the research vessel to avoid contamination. The glass plate was immersed perpendicular to the sea surface and withdrawn at a controlled rate of $\sim 17 \mathrm{~cm} \mathrm{~s}^{-1}$. SML samples adhered to the plate and were collected in an acid cleaned and rinsed bottle using a Teflon wiper (Cunliffe and Wurl, 2014). All sampling equipment was cleaned with acid $(10 \% \mathrm{HCl})$ and rinsed in MilliQ before sampling. In addition, all sampling devices were copiously rinsed with seawater from the respective depth when the sampling site was reached.

The ULW sample was collected with a LIMNOS water sampler (Hydro-bios) that had two acid cleaned $(10 \% \mathrm{HCl})$ and MilliQ rinsed plastic bottles attached to it. A weight attached to the LIMNOS sampler ensured that the bottles could not float to the surface during sampling. Since long waves rather than short breaking waves were most prominent, the depth of the LIMNOS sampler could be adjusted manually by keeping a marker on the rope continuously at the surface during sampling. Sampling of the ULW took about $30 \mathrm{~s}$ in total, keeping depth variations to a minimum.

\section{Transparent Exopolymer Particles (TEP)}

The abundance and area of TEP were measured microscopically (Engel, 2009). Depending on the concentration of TEP, 10$30 \mathrm{ml}$ of the sample was filtered onto a $0.4 \mu \mathrm{m}$ Nuclepore 


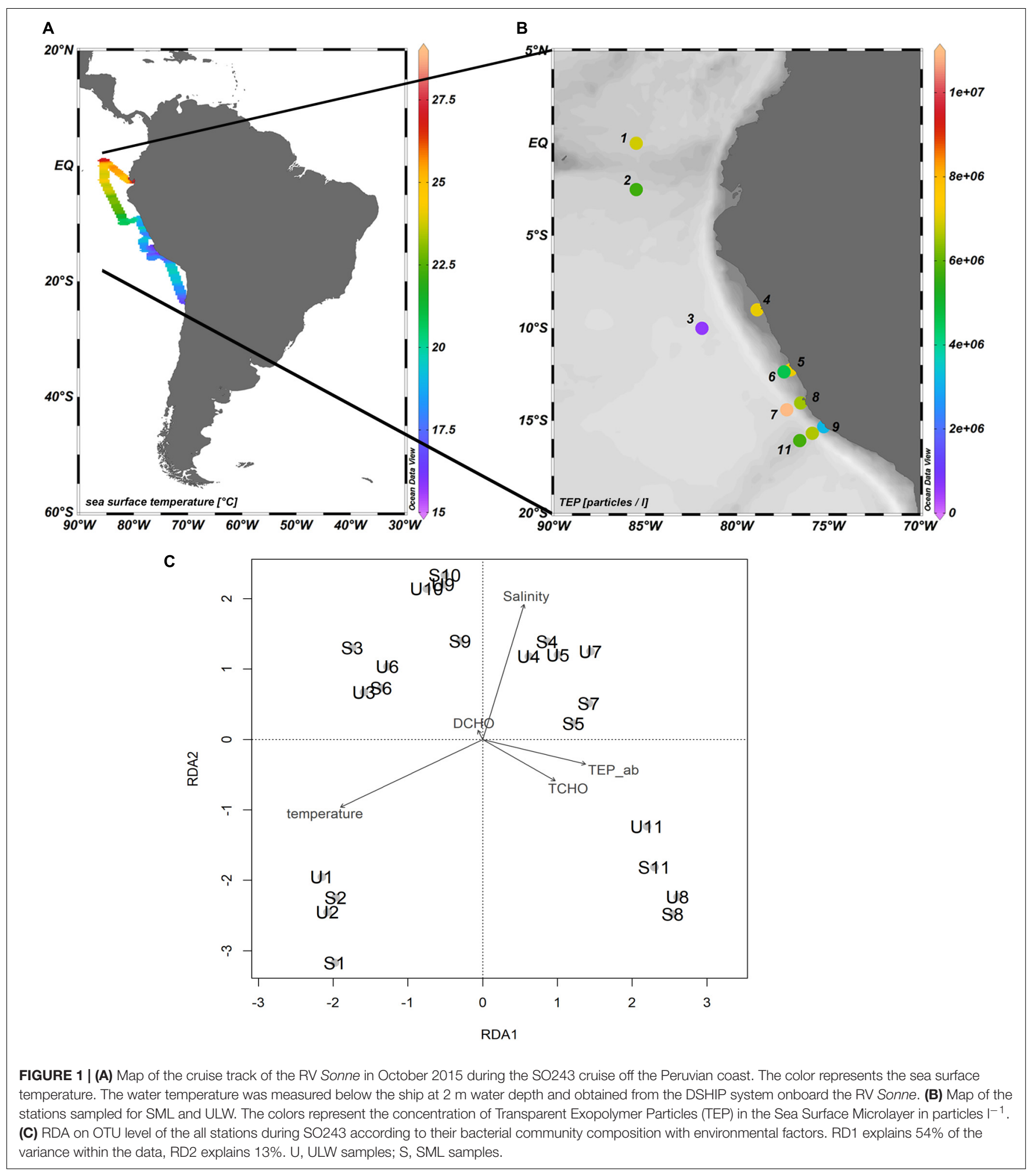

membrane (Whatman), and stained with $1 \mathrm{ml}$ Alcian Blue solution $\left(0.2 \mathrm{gl}^{-1} \mathrm{w} / \mathrm{v}\right)$ for $3 \mathrm{~s}$. Filters were subsequently mounted on Cytoclear ${ }^{\circledR}$ slides and stored at $-20^{\circ} \mathrm{C}$. The Zeiss Axio Scope. A1 (Zeiss) and the AxioCam MRc (Zeiss) were used to analyze two filters per sample with 30 images each. The pictures were saved using AxioVision LE64 Rel. 4.8 (Zeiss) with a resolution of $1388 \times 1040$ pixels. All particles bigger than $0.2 \mu \mathrm{m}^{2}$ were analyzed. Subsequent image analysis was conducted with ImageJ (Schneider et al., 2012). Two filters of $30 \mathrm{ml}$ MilliQ water served as a blank. 


\section{Total and Dissolved Combined Carbohydrates}

$20 \mathrm{ml}$ samples were collected into combusted glass vials $(8 \mathrm{~h}$, $500^{\circ} \mathrm{C}$ ) for the analysis of total and dissolved hydrolysable carbohydrates $>1 \mathrm{kDa}$ ( $\mathrm{TCHO}$ and $\mathrm{DCHO}$, respectively). DCHO samples were filtered through a $0.45 \mu \mathrm{m}$ Acrodisc $^{\circledR}$ syringe filter (Millipore) prior to filling the glass vials. Both $\mathrm{TCHO}$ and $\mathrm{DCHO}$ samples were stored at $-20^{\circ} \mathrm{C}$ until analysis. Prior to analysis, samples were desalinated using membrane dialysis (1 kDa MWCO, Spectra Por) at $1^{\circ} \mathrm{C}$ for $5 \mathrm{~h}$ with a subsequent hydrolysis step for $20 \mathrm{~h}$ at $100^{\circ} \mathrm{C}$ with $0.8 \mathrm{M} \mathrm{HCl}$ final concentration and neutralization through acid evaporation $\left(\mathrm{N}_{2}\right.$, for $5 \mathrm{~h}$ at $\left.50^{\circ} \mathrm{C}\right)$. High performance anion exchange chromatography with pulsed amperometric detection (HPAECPAD) was applied on a Dionex ECS 3000 ion chromatography system (Engel and Händel, 2011) to measure the samples. Two replicates per sample were analyzed.

\section{Bacterial Numbers}

Bacterial numbers were determined using flow cytometry from a $4 \mathrm{ml}$ sample that was fixed with $200 \mu \mathrm{l}$ glutaraldehyde (GDA, $1 \%$ final concentration). Samples were stored at $-20^{\circ} \mathrm{C}$ for at most 2.5 months until analysis and were stained with SYBR Green I (Molecular Probes) prior to quantification using a flow cytometer equipped with a $488 \mathrm{~nm}$ laser (Becton \& Dickinson FACScalibur). A plot of side scatter (SSC) vs. green fluorescence (FL1) was used to detect the unique signature of the bacterial cells. The internal standard consisted of yellow-green latex beads (Polysciences, $0.5 \mu \mathrm{m}$ ).

\section{DNA Extraction and Bacterial 16S rRNA Gene Sequencing}

For DNA extraction, $400 \mathrm{ml}$ of sample was filtered onto a Durapore membrane (Millipore, $47 \mathrm{~mm}, 0.2 \mu \mathrm{m}$ ) and stored at $-80^{\circ} \mathrm{C}$. Prior to DNA extraction, tubes containing the filters were immersed in liquid nitrogen and the filter was crushed with a pestle to make the cell membrane accessible for the DNA extraction buffers. DNA was extracted using a modified protocol from Zhou et al. (1996) by Wietz et al. (2015) and included bead-beating, phenol-chloroform-isoamyl alcohol purification, isopropanol precipitation and ethanol washing. An additional protein-removal step by salting was added. DNA concentrations in the sample were measured with a Qubit Fluorometer (Life Technologies) and stored at $-20^{\circ} \mathrm{C}$.

Bacterial 16S rRNA gene amplicons were sequenced on a MiSeq platform (Illumina). Primers used to PCR amplify the region of interest were $341 \mathrm{~F}$ and 805R (Herlemann et al., 2011) recommended in the MiSeq protocol (Illumina). The samples were prepared according to the manufacturer's instructions with modifications. Three PCR steps were used to amplify the region of interest: one PCR amplifying the 16S rRNA gene amplicons, one ligating the amplicons to the adapters and the third to add the index primers to the adapters with 20, 10, and 8 cycles, respectively. The PCR cycling conditions were the same for all three steps: initial denaturation at $95^{\circ} \mathrm{C}$ for $3 \mathrm{~min}$, cycles with denaturation at $95^{\circ} \mathrm{C}$ for $30 \mathrm{~s}$, annealing at $55^{\circ} \mathrm{C}$ for $30 \mathrm{~s}$ and elongation at $72^{\circ} \mathrm{C}$ for $30 \mathrm{~s}$. A final elongation was carried out at $72^{\circ} \mathrm{C}$ for $5 \mathrm{~min}$. DNA was purified using the AMPure XP bead purification kit according to the manufacturer's instructions (Beckmann Coulter).

\section{Bioinformatics and Statistical Analyses}

Sequences were quality-trimmed using mothur v 1.35.1 (Schloss et al., 2009). Sequences shorter than 400 bp or longer than 467 bp were removed, as well as sequences with more than 8 homopolymers and any ambiguous bases. Sequences were aligned with the SILVA alignment as reference (Quast et al., 2013). After discarding sequences that aligned outside the majority of the dataset and removing chimeras, the Greengenes database (DeSantis et al., 2006) was used to classify the sequences which were deposited at the European Nucleotide Archive (ENA accession number PRJEB22038).

Statistical analyses were conducted in R (R Core Team, 2014). Ocean Data View was used to compute the map of the cruise (Schlitzer, 2013). The significance of enrichment/depletion of the abundant families was obtained by testing the enrichment factor $(\mathrm{EF})$ of the respective families against an $\mathrm{EF}=1$ (signifying no enrichment or depletion) with a $t$-test. The EF was used to compare the concentration of substance A in the SML compared to the ULW and was calculated using the following formula:

$$
E F=[A]_{\mathrm{SML}} /[A]_{\mathrm{ULW}}
$$

Where [A] represents the concentration of a certain substance in the SML or ULW (World Health Organization, 1995). An $\mathrm{EF}>1$ indicates enrichment, whereas an EF $<1$ indicates depletion of a certain substance in the SML compared to the ULW.

The correlation of the enriched families with environmental factors was calculated using a Spearman rank correlation because the bacterial family abundances were not normally distributed.

\section{Data Obtained From the Ship}

Abiotic data, such as irradiance, wind speed and water temperature was obtained from the DSHIP system on the RV Sonne. Water temperature was measured at a depth of $2 \mathrm{~m}$, wind speed was measured $35 \mathrm{~m}$ above the water surface.

\section{RESULTS}

\section{Transparent Exopolymer Particles and Combined Carbohydrates}

Figure 1 shows the sea surface temperature (Figure 1A) and TEP abundance (Figure 1B) during the cruise. TEP were found in abundances ranging from $5.78 \times 10^{5}$ to $1.09 \times 10^{7}$ particles $1^{-1}$ (average of $5.89 \times 10^{6} \pm 2.47 \times 10^{6}$ particles $1^{-1}$ ) in the SML compared to $6.58 \times 10^{5}$ to $1.18 \times 10^{7}$ particles $1^{-1}$ (average of $4.43 \times 10^{6} \pm 3.37 \times 10^{6}$ particles $1^{-1}$ ) in the ULW. The highest abundances of TEP were found in the to upwelling, close to the Peruvian coast between stations 4-8 (Figure 1B). TCHO concentrations varied between 543 and $1204 \mathrm{nmol}^{-1}$ in the SML and 463 and $1495 \mathrm{nmol}$ 
$1^{-1}$ in the ULW (Supplementary Figure S2), whereas DCHO concentrations ranged from 352 to $696 \mathrm{nmol} \mathrm{l}^{-1}$ in the SML and 228 to $1200 \mathrm{nmol} \mathrm{l}^{-1}$ in the ULW (Supplementary Figure S3).

\section{Bacterial Abundance and Community Composition}

The total bacterial numbers determined by flow cytometry were not significantly different between the SML and the ULW $(p=0.89, t$-test) and were strongly correlated (rho $=0.94$, $p<0.05)$. Bacterial abundances ranged from $4.64 \times 10^{5}$ to $1.75 \times 10^{6}$ cells ml ${ }^{-1}$ (average of $8.89 \times 10^{5} \pm 4.31 \times 10^{5}$ cells $\mathrm{ml}^{-1}$ ) in the SML and $4.42 \times 10^{5}$ to $1.89 \times 10^{6} \mathrm{cells} \mathrm{ml}^{-1}$ (average of $9.18 \times 10^{5} \pm 4.65 \times 10^{5}$ cells $\mathrm{ml}^{-1}$ ) in the ULW, respectively (Supplementary Table S3). EFs varied between 0.80 and 1.28 with an average of $0.98 \pm 0.13$.

The bacterial community structure of the SML and the ULW was assessed based on 16S rRNA gene high-throughput sequencing. Figure 1C shows a RDA plot of all stations during the cruise, highlighting the general similarity of the bacterial communities between the SML and the ULW at almost all stations. At some stations (S1, 3, 4, 5, 7, 9) one or both of the depths sampled was more similar to another station than to the corresponding depth at the same station. No clear trend could be observed between the location of the stations and the similarity of the bacterial communities (e.g., distance from the coast). The bacterial diversity was similar between SML and ULW communities with no clear trend of either depth having a higher diversity (Supplementary Table S2).

\section{Bacterial Families Enriched in the SML}

Twenty four families were identified that made up at least $1 \%$ each of the total community at two stations or more considering both depths (Supplementary Table S1). These families were considered to be important for the community composition and analyzed in further detail. All other families were summarized as 'others.' None of the bacterial families showed a significant depletion in the SML compared to the ULW ( $t$-test against an $\mathrm{EF}=1, p<0.05$ ) (Figure 2A). Four families (unknown Flavobacteriales, Flavobacteriaceae, Cryomorphaceae, unknown Bacteroidetes) were however, significantly enriched in the SML compared to the ULW throughout the cruise ( $t$-test against an $\mathrm{EF}=1, p<0.05$ ) (Figure 2A), with all members belonging to the phylum Bacteroidetes. Figure $2 \mathbf{B}$ shows that the four families were consistently enriched at almost all stations analyzed.

The relative abundances of all four families that were significantly enriched in the SML (Figure 2A) were pooled to calculate the overall relative abundance of SML enriched bacterial families. Figure 3 shows the community composition across all stations in the SML and ULW. The enriched families made up $24 \pm 8 \%$ in the SML and $20 \pm 7 \%$ in the ULW across all stations (Figure 4A). While the means of the relative abundance of the combined enriched families in the SML and ULW did not differ significantly ( $t$-test, $p=0.25$ ), the EFs during the cruise were significantly different from 1 ( $t$-test against an $\mathrm{EF}=1, p<0.05)$. Out of the four SML enriched bacterial families, Flavobacteriaceae, and Cryomorphaceae were dominating (Figure 4A). The composition of the enriched
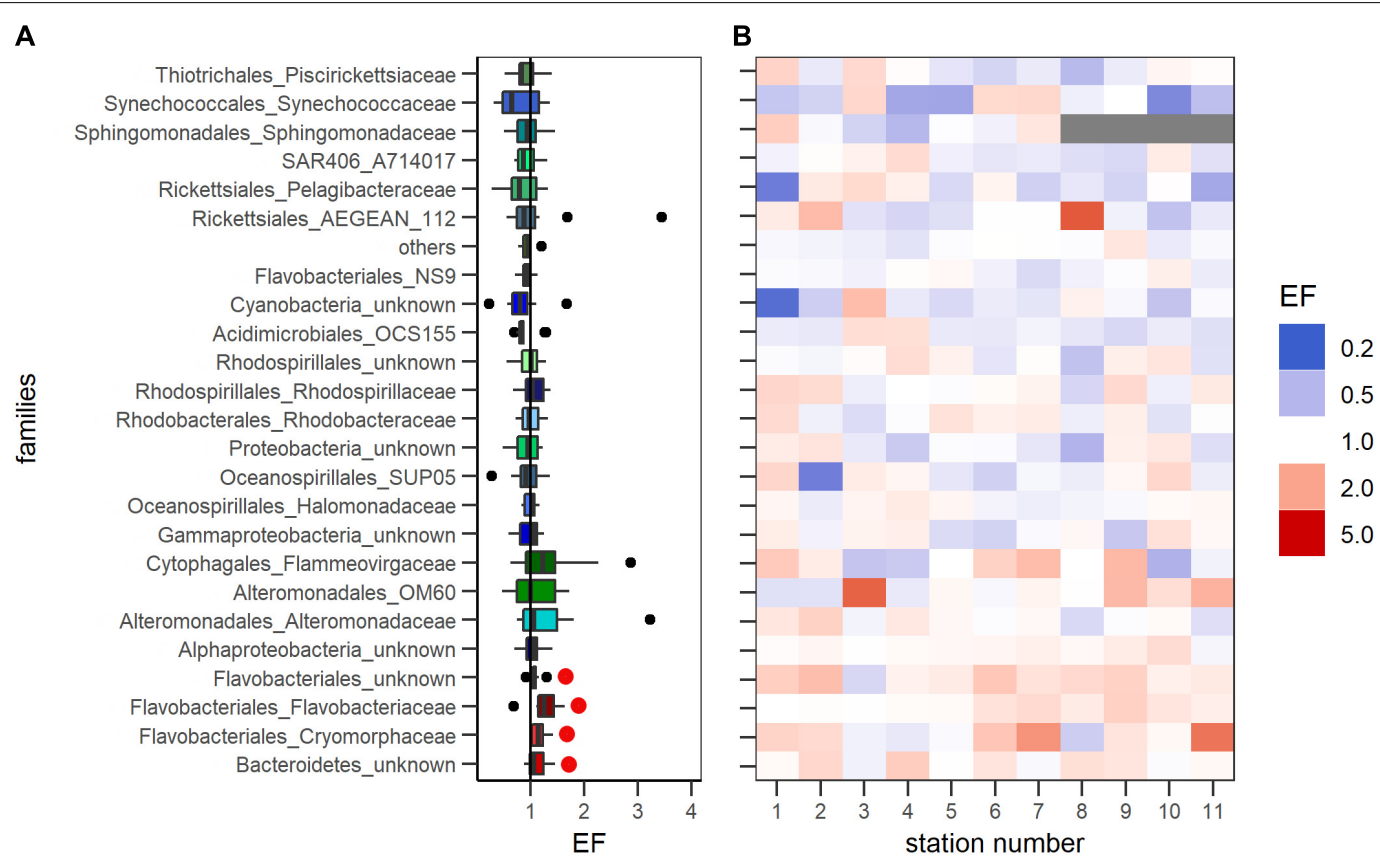

FIGURE 2 || Enrichment of bacterial families that make up at least 1\% of the total bacterial community in at least two stations. (A) Enrichments during the whole cruise (11 stations) were combined. Red, Bacterial families that were significantly enriched in the SML. blue/green, bacterial families that showed no significant changes with depth. Black line indicates no change between depths (EF = 1). Black circles, outliers. Red dots mark significant enrichment of bacterial families throughout the cruise. (B) Enrichment of families according to each individual station. Blue indicates a depletion, white no change and red an enrichment of a certain bacterial family at the respective station. An EF of 0.2 indicates a five-fold decrease, an EF of 5 a five-fold increase of a certain bacterial species in the SML. 

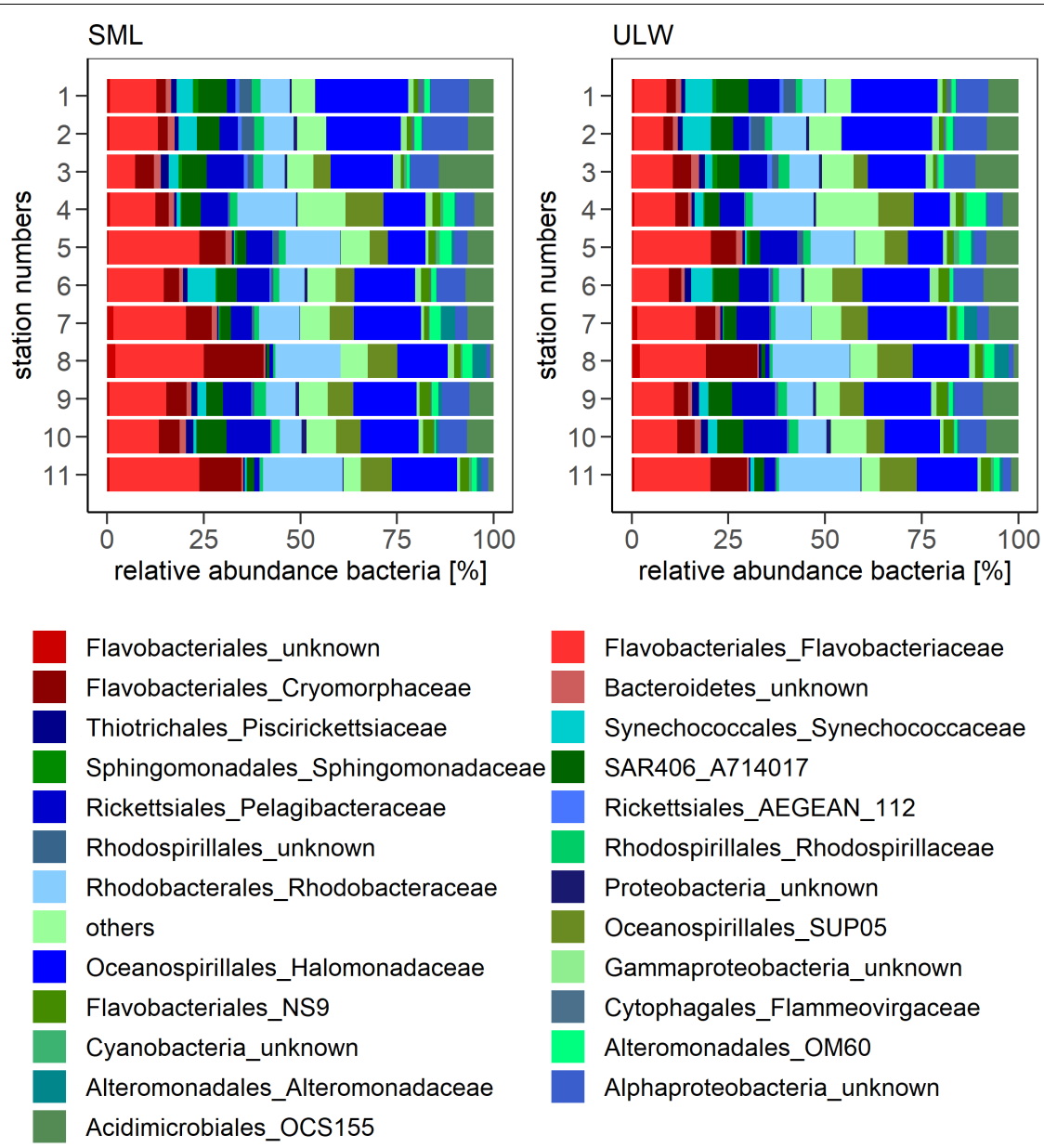

Flavobacteriales_Flavobacteriaceae

Bacteroidetes_unknown

Synechococcales_Synechococcaceae

SAR406_A714017

Rickettsiales_AEGEAN_112

Rhodospirillales_Rhodospirillaceae

Proteobacteria_unknown

Oceanospirillales_SUP05

Gammaproteobacteria_unknown

Cytophagales_Flammeovirgaceae

Alteromonadales_OM60

Alphaproteobacteria_unknown

FIGURE 3 | Bacterial community composition at all stations given as relative abundances at family level. Families that make up > 1\% in at least two stations are shown. Red, significantly enriched families in the SML. Blue/green, bacterial families showing no differences between SML and ULW.

bacterial families was similar between SML and ULW, the overall relative abundance was lower in the ULW though (Figure 4A). The five most abundant OTUs of Flavobacteriaceae, Cryomorphaceae, and unknown Flavobacteriales were further analyzed. Figure 4B shows their closest neighbors. The majority of unknown Flavobacteriales OTUs cluster rather closely with the Cryomorphaceae. Figure 3 shows that the community differences were higher between stations than between SML and ULW, which showed similar bacterial communities. The most abundant families at both depths were Flavobacteriaceae, Rhodobacteraceae as well as Halomonadales at some stations.

\section{Control of SML-Enriched Families}

The relationship of the pooled enriched bacterial families with abiotic and biotic factors (nutrients, salinity, radiation, wind speed, water temperature) was investigated to elucidate the driving factors of bacterial community enrichment in the SML. The SML enriched bacterial families (as calculated in the previous section) were positively correlated with nutrients such as phosphate $\left(\mathrm{PO}_{4}\right)$, nitrate $\left(\mathrm{NO}_{3}\right)$, silicate $\left(\mathrm{SiO}_{2}\right)$, and salinity and were negatively correlated with seawater temperature
(rhosML $=-0.93$, rhoulw $=-0.91$, respectively, $p<0.05$ ) and wind speed (rho $=-0.64, p<0.05$ ) (Table 1). The enrichment of the pooled SML enriched families did not correlate significantly with wind speed. This means that high wind speeds were cooccurring with low abundances of SML enriched families not only in the SML, but also in the ULW, thus not affecting the EF. No correlation was found between enriched bacterial families and instantaneous irradiation intensity neither in the SML nor in the ULW. The SML enriched bacterial families showed a significant positive correlation with both TEP abundance and area in the ULW ( rho $_{\text {abundance }}=0.80$ and $\mathrm{rho}_{\text {area }}=0.80$, respectively, $p<0.05$ ), and were also positively correlated with TCHO in the ULW (rho $=0.71, p<0.05$ ), but showed no correlation with DCHO.

\section{DISCUSSION}

The overall bacterial community composition was similar between SML and ULW throughout the cruise (Figure 1C), which is in accordance with some previous studies (Agogué 
A

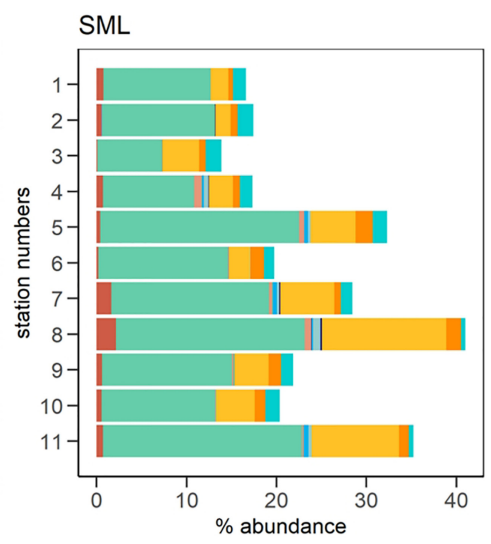

Flavobacteriales_unknown

Flavobacteriaceae_unknown

Flavobacteriaceae_Tenacibaculum

Flavobacteriaceae_Sediminicola

Flavobacteriaceae_Olleya

Flavobacteriaceae_Kordia

Flavobacteriaceae_Flavobacterium_frigidarium

Flavobacteriaceae_Coccinimonas

Cryomorphaceae_Owenweeksia

Cryomorphaceae_Crocinitomix

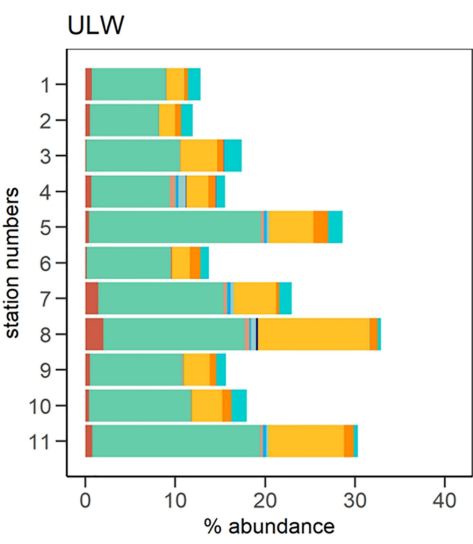

Flavobacteriaceae_Winogradskyella

Flavobacteriaceae_Ulvibacter_litoralis

Flavobacteriaceae_Sufflavibacter_maritimus

Flavobacteriaceae_Polaribacter

Flavobacteriaceae_Lutimonas

Flavobacteriaceae_Gaetbulibacter_marinus

Flavobacteriaceae_Flavobacterium

Cryomorphaceae_unknown

Cryomorphaceae_Fluviicola

Bacteroidetes_unknown

B

91 Bizionia arctica SM1203 (NR 137224.1)

39 Bizionia arctica SM1203 (KJ508751.1)

50 Formosa sp. SS15.5 (KC160811.1)

Formosa haliotisLMG 28520 (NR 145850.1)

31 of Bizionia sp. 882 (KP006529.1)

Bizionia sp. BB1 (KP006528.1)

1) Gelidibacteralgens (AF001367.1)

17. Lacinutrix sp. SS10.11 (KC160706.1)

77 Lacinutrix Sp. SS10.11 (KC160706.1) Lacinutrix sp. 7 Alg 4 (KUS10085.1)

22 OTU Flavobacteriacese 3

47 OTU Flavobacteriaceae

77 LTU Flavobacteriacesee 2

43 Flavobacterium sp. SCGC AAA300-K05 (HQ675321.1)

\&f OTU Flavobacteriacese 4

Flavobacterium sp. SCGC AAA298-021 (HQ675267.1)

67

8s Aquimarina agarivorans HQM9 (NR 136817.1)

Aquimarina agarilytica ZC1 (NR 116794.1)

48 Tenacibaculum Sp. MED341 (EU253574.1)

LOTU Flavobacteriaceae 1

T2 Tenacibaculum mesophilum HNSO44 (JN128278.1) Tenacibaculumaiptasioe ECSMB75 (KU982638.1)

Phaeocystidibacter marisubriG18 (NR 136475.1)

54 Cowerweeksia sp. MEBic09403 (KJ418108.1)

35 COTU Cryomorphaceae 3

100 Owenweeksia hongkongensis UST20020801 (NR 040990.1)

100

OTU Cryomorphaceae 1

24 OTU Flavobacteriales

43 OTU Flavobacteriales 2

43 TOTU Flavobacteriales 1

- OTU Cryomorphacese ?

Q8 - OTU Cryomorphaceses

L OTU Cryomorphaceee 4

- OTU Flavobacteriales 4

Brumimicrobium sp. N62 (KR528475.1)

Unculured alpha proteobacterium SW08-paRBL.02-37 (JF917203.1)

79 Uncultured Caulobacter sp. PMS -4.6-21 (JQ177421.1)

Uncutured Caulobacter sp. PMS -4.6-05 (JQ177405.1)

FIGURE 4 | (A) Community composition of enriched bacterial families at species level. (B) Phylogenetic tree of the most abundant OTUs of unknown

Flavobacteriales family, Flavobacteriaceae, and Cryomorphaceae. The closest relatives identified at the genus level were included in the tree, Alphaproteobacteria were used as an outgroup. The sequences were aligned with MUSCLE. The tree was computed with the maximum likelihood method. The scale bar represents $20 \%$ sequence divergence. Numbers at nodes represent bootstrap values $(n=100)$. 
TABLE 1 | Correlations of enriched bacterial families in the SML with different biotic and abiotic parameters in the SML and the ULW.

\begin{tabular}{|c|c|c|}
\hline Parameter & rhosmL & rhoulw \\
\hline TEP & - & 0.80 \\
\hline TEP area & - & 0.80 \\
\hline $\mathrm{TCHO}$ & - & 0.71 \\
\hline $\mathrm{PO}_{4}$ & 0.84 & 0.85 \\
\hline $\mathrm{NO}_{3}$ & 0.73 & 0.75 \\
\hline $\mathrm{NO}_{2}$ & - & - \\
\hline $\mathrm{SiO}_{2}$ & 0.65 & 0.72 \\
\hline Salinity & 0.77 & 0.73 \\
\hline Radiation & - & - \\
\hline Wind speed & -0.64 & - \\
\hline Water temperature & -0.93 & -0.91 \\
\hline
\end{tabular}

Only significant correlations $(p<0.05)$ are displayed.

et al., 2005a; Stolle et al., 2011; Taylor and Cunliffe, 2014). The use of a metal screen sampler might potentially have led to higher SML enrichments as was found previously by Agogué et al. (2004). The same authors showed in a later study that the different sampling methods (metal screen, glass plate sampler and membrane) all retrieved the same bacterial species (Agogué et al., 2005a), thus we are confident that our samples are a good representation of the SML bacterial community during the cruise, potentially rather underestimating the enrichment of bacteria in the SML. Figure $\mathbf{1 C}$ shows that the bacterial communities cluster rather by station than by depth. A strong correlation (rho $=0.94, p<0.05$ ) between bacterial numbers in the SML and ULW was observed, suggesting a close coupling between the two environments. The concentration of TEP in the SML on the other hand seemed to be less determined by the concentration in the ULW, but rather by the station location as discussed previously in detail by Zäncker et al. (2017).

The bacterial community in the SML as well as the ULW was dominated by Flavobacteriaceae, Cryomorphaceae (both members of Bacteroidetes), Rhodobacteraceae, and Halomonadaceae. Members of Bacteroidetes have been found to be abundant in the SML in the Baltic Sea in a previous study (Stolle et al., 2011), corroborating our findings. In contrast to a previous study (Franklin et al., 2005), the bacterial diversity did not differ significantly between the SML and the ULW during our cruise. While the bulk of the bacterial community did not show clear differences between the SML and ULW, four out of the 24 abundant families ( $>1 \%$ relative abundance at two or more stations) that were all members of the Bacteroidetes, showed a significant enrichment in the SML considering all stations. While the enrichment (Figure 2A) was not high (average EF of $1.22 \pm 0.18$ ), it was consistent throughout the cruise (Figure 2B). The positive correlations of the abundance of the enriched bacterial community with nutrient concentrations and salinity and the negative correlation with water temperature indicate that these bacteria were more abundant at upwelling stations (S7-11) compared to the rest of the stations (S1-S6) (Supplementary Figure S1).

Additional factors possibly influencing the bacterial community composition were analyzed. Several factors have been proposed to control the bacterial diversity in the SML in situ, including meteorological conditions, exposure to UV radiation, aerosol deposition and organic matter availability (Carlucci et al., 1985; Agogué et al., 2005a; Stolle et al., 2010, 2011; Nakajima et al., 2013; Astrahan et al., 2016). During this study, a negative correlation of the SML abundance of enriched bacterial families with wind speed was found, which corroborates earlier findings that high wind speeds disrupt the SML and seem to prevent bacterial enrichment in the SML of the Baltic Sea and during a wind wave tunnel experiment (Rahlff et al., 2017).

No correlation was found between the abundance of enriched bacterial families and instantaneous irradiation intensity suggesting UV radiation was not the main factor driving the bacterioneuston community composition. However, the correlation was conducted using instantaneous irradiation only, the irradiation history was not considered and thus an effect of the irradiation history cannot be excluded. In a laboratory study for example, bacteria responded to irradiation exposure after 1-2 h (Joux et al., 1999). Furthermore, the difference of UV radiation intensity between the SML and the ULW was not measured. At high light intensities the difference between the light entering the water and the light that reaches $1 \mathrm{~m}$ can be high (Fleischmann, 1989). Considering that light intensity exponentially decreases in the water column, it seems reasonable to expect differences in the light intensities between the SML and the ULW at $20 \mathrm{~cm}$, though.

Next to in situ growth of bacteria in the SML, the bacterionneuston community composition might also be influenced by factors influencing the upward transport of bacteria such as bubbles and positively buoyant particles, particularly TEP (Azetsu-Scott and Passow, 2004; Agogué et al., 2005a; Joux et al., 2006). Among the most abundant enriched families were Flavobacteriales, which have been shown previously to be involved in polysaccharide degradation (Buchan et al., 2014; Teeling et al., 2016). A direct link with TEP and TEP precursors, such as polysaccharides produced by phytoplankton, has also been demonstrated for Rhodobacterales, Flavobacteriales, and Alteromonadales (Buchan et al., 2014; Taylor et al., 2014; Teeling et al., 2016; Taylor and Cunliffe, 2017).

The correlations between enriched families and TEP found in the present study suggest that enriched families might be associated with TEP. Since TEP are positively buoyant (AzetsuScott and Passow, 2004), it seems plausible that TEP can act as a transport mechanism for the bacteria attached from the ULW to the SML, which might be one way for bacteria to be enriched in the SML. The percentage of the total bacterial community that is attached to TEP has been previously observed to be 0.5-20\% (Mari and Kiorboe, 1996; Busch et al., 2017). Assuming that most members of the four enriched families in the SML and ULW live attached to TEP, the previously 
published numbers are in agreement with the relative abundance of enriched families in the SML and ULW (on average $24 \pm 8 \%$ in the SML and $20 \pm 7 \%$ in the ULW) found during this study. At the same time, this would mean that the potential importance of TEP is limited to only part of the total bacterial community. The similar community structure of the SML and ULW throughout the cruise furthermore suggests a limited influence. Further studies would be needed to analyze the exact effect of TEP on the bacterionneuston community composition including whether attachment to TEP enhances growth in situ in the SML, or whether it enhances the transport up from the ULW. The missing correlation of enriched bacterial families and TEP in the SML might be caused by wind speed affecting the bacterionneuston community (as discussed above), but not TEP in the SML (as discussed in Zäncker et al., 2017).

Our study reports the bacterial community composition in the SML and ULW off the Peruvian coast. In addition, it discusses potential influencing factors of the bacterionneuston community composition such as nutrients, wind speed, and interactions with organic matter. Future studies are necessary to elucidate the potential impact of upward transport of bacteria into the SML further.

\section{AUTHOR CONTRIBUTIONS}

All authors listed have made a substantial, direct and intellectual contribution to the work, and approved it for publication.

\section{REFERENCES}

Agogué, H., Casamayor, E. O., Bourrain, M., Obernosterer, I., Joux, F., Herndl, G. J., et al. (2005a). A survey on bacteria inhabiting the sea surface microlayer of coastal ecosystems. FEMS Microbiol. Ecol. 54, 269-280. doi: 10.1016/j.femsec. 2005.04.002

Agogué, H., Joux, F., Obernosterer, I., and Lebaron, P. (2005b). Resistance of marine bacterioneuston to solar radiation. Appl. Environ. Microbiol. 71, 5282-5289. doi: 10.1128/AEM.71.9.5282-5289.2005

Agogué, H., Casamayor, E. O., Joux, F., Obernosterer, I., Dupuy, C., Lantoine, F., et al. (2004). Comparison of samplers for the biological characterization of the sea surface microlayer. Limnol. Oceanogr. Methods 2, 213-225. doi: 10.4319/ lom.2004.2.213

Aller, J. Y., Radway, J. C., Kilthau, W. P., Bothe, D. W., Wilson, T. W., Vaillancourt, R. D., et al. (2017). Size-resolved characterization of the polysaccharidic and proteinaceous components of sea spray aerosol. Atmos. Environ. 154, 331-347. doi: 10.1016/j.atmosenv.2017.01.053

Astrahan, P., Herut, B., Paytan, A., and Rahav, E. (2016). The impact of dry atmospheric deposition on the sea-surface microlayer in the SE Mediterranean Sea: an experimental approach. Front. Mar. Sci. 3:222. doi: 10.3389/fmars.2016. 00222

Azam, F., Smith, D. C., Steward, G. F., and Hagström, Å. (1993). Bacteria-organic matter coupling and its significance for oceanic carbon cycling. Microb. Ecol. 28, 167-179. doi: 10.1007/BF00166806

Azetsu-Scott, K., and Passow, U. (2004). Ascending marine particles: significance of transparent exopolymer particles (TEP) in the upper ocean. Limnol. Oceanogr. 49, 741-748. doi: 10.4319/lo.2004.49.3.0741

Buchan, A., LeCleir, G. R., Gulvik, C. A., and Gonzalez, J. M. (2014). Master recyclers: features and functions of bacteria associated with phytoplankton blooms. Nat. Rev. Microbiol. 12, 686-698. doi: 10.1038/nrmicro3326

\section{FUNDING}

This work was supported financially by the European Molecular Biology Organization (EMBO) through an EMBO Short-Term Fellowship [ASTF 118-2016]. Funding for analysis of the nutrient data was received by SOPRAN III (BMBF FKZ 03F0662A).

\section{ACKNOWLEDGMENTS}

We would like to thank the captain and crew of the RV Sonne during the SO243 cruise as well as the chief scientists of the cruise. We would like to especially thank Jon Roa for his help in sampling and on-board processing. Thanks also to Tania Klüver for measuring the bacterial cell abundances. We would also like to thank Martina Lohmann for the analysis of the nutrient data. Furthermore, we would like to thank Andreas Schramm for providing the laboratory space and technical support for the Illumina amplicon sequencing as well as for his helpful comments on the manuscript. We would also like to thank Britta Poulsen for her help in preparing the amplicon library and for carrying out the MiSeq sequencing.

\section{SUPPLEMENTARY MATERIAL}

The Supplementary Material for this article can be found online at: https://www.frontiersin.org/articles/10.3389/fmicb. 2018.02699/full\#supplementary-material

Busch, K., Endres, S., Iversen, M. H., Michels, J., Nothig, E.-M., and Engel, A. (2017). Bacterial colonization and vertical distribution of marine gel particles (TEP and CSP) in the arctic fram strait. Front. Mar. Sci. 4:166. doi: 10.3389/ fmars.2017.00166

Carlucci, A. F., Craven, D. B., and Henrichs, S. M. (1985). Surface-film microheterotrophs: amino acid metabolism and solar radiation effects on their activities. Mar. Biol. 85, 13-22. doi: 10.1007/BF00396410

Chin, W.-C., Orellana, M. V., and Verdugo, P. (1998). Spontaneous assembly of marine dissolved organic matter into polymer gels. Nature 391, 568-572. doi: $10.1038 / 35345$

Cunliffe, M., Harrison, E., Salter, M., Schäfer, H., Upstill-Goddard, R. C., and Murrell, C. (2009a). Comparison and validation of sampling strategies for the molecular microbial analysis of surface microlayers. Aquat. Microb. Ecol. 57, 69-77. doi: 10.3354/ame01330

Cunliffe, M., Salter, M., Mann, P. J., Whiteley, A. S., Upstill-Goddard, R. C., and Murrell, J. C. (2009b). Dissolved organic carbon and bacterial populations in the gelatinous surface microlayer of a Norwegian fjord mesocosm. FEMS Microbiol. Lett. 299, 248-254. doi: 10.1111/j.1574-6968.2009.01751.x

Cunliffe, M., Whiteley, A. S., Newbold, L., Oliver, A., Schäfer, H., and Murrell, J. C. (2009c). Comparison of bacterioneuston and bacterioplankton dynamics during a phytoplankton bloom in a fjord mesocosm. Appl. Environ. Microbiol. 75, 7173-7181. doi: 10.1128/AEM.01374-09

Cunliffe, M., Upstill-Goddard, R. C., and Murrell, J. C. (2011). Microbiology of aquatic surface microlayers. FEMS Microbiol. Rev. 35, 233-246. doi: 10.1111/j. 1574-6976.2010.00246.x

Cunliffe, M., and Wurl, O. (2014). Guide to Best Practices to Study the Ocean's Surface. Plymouth: Occasional Publications of the Marine Biological Association.

DeSantis, T. Z., Hugenholtz, P., Larsen, N., Rojas, M., Brodie, E. L., Keller, K., et al. (2006). Greengenes, a chimera-checked 16S rRNA gene database and 
workbench compatible with ARB. Appl. Environ. Microbiol. 72, 5069-5072. doi: 10.1128/AEM.03006-05

Dutz, J., Klein Breteler, W. C. M., and Kramer, G. (2005). Inhibition of copepod feeding by exudates and transparent exopolymer particles (TEP) derived from a Phaeocystis globosa dominated phytoplankton community. Harmful Algae 4, 929-940. doi: 10.1016/j.hal.2004.12.003

Engel, A. (2009). "Determination of marine gel particles," in Practical Guidelines for the Analysis of Seawater, ed. O. Wurl (Boca Raton, FL: CRC Press Taylor \& Francis Group), 125-142.

Engel, A., Bange, H. W., Cunliffe, M., Burrows, S. M., Friedrichs, G., Galgani, L., et al. (2017). The ocean's vital skin: toward an integrated understanding of the sea surface microlayer. Front Mar Sci 4:165. doi: 10.3389/fmars.2017.00165

Engel, A., and Galgani, L. (2016). The organic sea-surface microlayer in the upwelling region off the coast of Peru and potential implications for air-sea exchange processes. Biogeosciences 13, 989-1007. doi: 10.5194/bg-13-989-2016

Engel, A., and Händel, N. (2011). A novel protocol for determining the concentration and composition of sugars in particulate and in high molecular weight dissolved organic matter (HMW-DOM) in seawater. Mar. Chem. 127, 180-191. doi: 10.1016/j.marchem.2011.09.004

Engel, A., Thoms, S., Riebesell, U., Rochelle-Newall, E., and Zondervan, I. (2004). Polysaccharide aggregation as a potential sink of marine dissolved organic carbon. Nature 428, 929-932. doi: 10.1038/nature02453

Fleischmann, E. M. (1989). The measurement and penetration of UV radiation into tropical marine water. Limnol. Oceanogr. 34, 1623-1629. doi: 10.4319/lo.1989. 34.8.1623

Franklin, M. P., McDonald, I. R., Bourne, D. G., Owens, N. J. P., Upstill-Goddard, R. C., and Murrell, J. C. (2005). Bacterial diversity in the bacterioneuston (sea surface microlayer): the bacterioneuston through the looking glass. Environ. Microbiol. 7, 723-736. doi: 10.1111/j.1462-2920.2004.00736.x

Harvey, G. (1966). Microlayer collection from the sea surface: a new method and intial results. Limnol. Ocean 11, 608-613. doi: 10.4319/lo.1966.11.4.0608

Herlemann, D. P. R., Labrenz, M., Jürgens, K., Bertilsson, S., Waniek, J. J., Andersson, A. F., et al. (2011). Transitions in bacterial communities along the $2000 \mathrm{~km}$ salinity gradient of the Baltic Sea. ISME J. 5, 1571-1579. doi: 10.1038/ ismej.2011.41

Joux, F., Agogue, H., Obernosterer, I., Dupuy, C., Reinthaler, T., Herndl, G. J., et al. (2006). Microbial community structure in the sea surface microlayer at two contrasting sites in the northwestern Mediterranean Sea. Aquat. Microb. Ecol. 42, 91-104. doi: 10.3354/ame042091

Joux, F., Jeffrey, W. H., Lebaron, P., and Mitchell, D. L. (1999). Marine bacterial isolates display diverse reponses to UV-B radiation. Appl. Environ. Microbiol. $65,3820-3827$.

Judd, K. E., Crump, B. C., and Kling, G. W. (2006). Variation in dissolved organic matter controls bacterial production and community composition. Ecology 87, 2068-2079. doi: 10.1890/0012-9658(2006)87[2068:VIDOMC]2.0.CO;2

Liss, P. S., and Duce, R. A. (2005). The Sea Surface and Global Change. Cambridge: Cambridge University Press.

Malej, A., and Harris, R. P. (1993). Inhibition of copepod grazing by diatom exudates: a factor in the development of mucus aggregates? Mar. Ecol. Prog. Ser. 96, 33-42. doi: 10.3354/meps096033

Mari, X., and Kiorboe, T. (1996). Abundance, size distribution and bacterial colonization of transparent exopolymeric particles (TEP) during spring in the Kattegat. J. Plankton Res. 18, 969-986. doi: 10.1093/plankt/18.6.969

Meiners, K., Krembs, C., and Gradinger, R. (2008). Exopolymer particles: microbial hotspots of enhanced bacterial activity in Arctic fast ice (Chukchi Sea). Aquat. Microb. Ecol. 52, 195-207. doi: 10.3354/ame01214

Nakajima, R., Tsuchiya, K., Nakatomi, N., Yoshida, T., Tada, Y., Konno, F., et al. (2013). Enrichment of microbial abundance in the sea-surface microlayer over a coral reef: implications for biogeochemical cycles in reef ecosystems. Mar. Ecol. Prog. Ser. 490, 11-22. doi: 10.3354/meps10481

Naumann, E. (1917). Über das Neuston des Süsswassers. Biol. Cent 37, 98-106.

Obernosterer, I., Catala, P., Lami, R., Caparros, J., Ras, J., Bricaud, A., et al. (2008). Biochemical characteristics and bacterial community structure of the sea surface microlayer in the South Pacific Ocean. Biogeosci. Dis. 4, 693-705. doi: 10.5194/bg-5-693-2008

Ortega-Retuerta, E., Passow, U., Duarte, C., and Reche, I. (2009). Effects of ultraviolet B radiation on (not so) transparent exopolymer particles. Biogeosciences 6, 3071-3080. doi: 10.5194/bg-6-3071-2009
Passow, U. (2000). Formation of transparent exopolymer particles, TEP, from dissolved precursor material. Mar. Ecol. Prog. Ser. 192, 1-11. doi: 10.3354/ meps192001

Passow, U. (2002). Transparent exopolymer particles in aquatic environments. Prog. Oceanogr. 55, 287-333. doi: 10.1016/S0079-6611(02)00138-6

Passow, U., and Alldredge, A. (1999). Do transparent exopolymer particles (TEP) inhibit grazing by the euphausiid Euphausia pacifica? J. Plankton Res. 21, 2203-2217. doi: 10.1093/plankt/21.11.2203

Passow, U., Shipe, R. F., Murray, A., Pak, D. K., Brzezinski, M. A., and Alldredge, A. L. (2001). The origin of transparent exopolymer particles (TEP) and their role in the sedimentation of particulate matter. Cont. Shelf Res. 21, 327-346. doi: 10.1016/S0278-4343(00)00101-1

Quast, C., Pruesse, E., Yilmaz, P., Gerken, J., Schweer, T., Yarza, P., et al. (2013). The SILVA ribosomal RNA gene database project: improved data processing and web-based tools. Nucleic Acids Res. 41, 590-596. doi: 10.1093/nar/gks 1219

R Core Team (2014). R: A Language and Environment for Statistical Computing. Vienne: R Foundation for Statistical Computing.

Rahlff, J., Stolle, C., Giebel, H.-A., Brinkhoff, T., Ribas-Ribas, M., Hodapp, D., et al. (2017). High wind speeds prevent formation of a distinct bacterioneuston community in the sea-surface microlayer. FEMS Microbiol. Ecol. 93:fix041. doi: $10.1093 /$ femsec/fix 041

Schlitzer, R. (2013). Ocean Data View 4.5.7. Bremerhaven: Alfred Wegener Institute.

Schloss, P. D., Westcott, S. L., Ryabin, T., Hall, J. R., Hartmann, M., Hollister, E. B., et al. (2009). Introducing mothur: open-source, platform-independent, community-supported software for describing and comparing microbial communities. Appl. Environ. Microbiol. 75, 7537-7541. doi: 10.1128/AEM. 01541-09

Schneider, C. A., Rasband, W. S., and Eliceiri, K. W. (2012). NIH image to image J: 25 years of image analysis. Nat. Methods 9, 671-675. doi: 10.1038/nmeth.2089

Schuster, S., and Herndl, G. J. (1995). Formation and significance of transparent exopolymeric particles in the northern Adriatic Sea. Mar. Ecol. Prog. Ser. 124, 227-236. doi: 10.3354/meps124227

Stolle, C., Labrenz, M., Meeske, C., and Jürgens, K. (2011). Bacterioneuston community structure in the southern baltic sea and its dependence on meteorological conditions. Appl. Environ. Microbiol. 77, 3726-3733. doi: 10. 1128/AEM.00042-11

Stolle, C., Nagel, K., Labrenz, M., and Jürgens, K. (2010). Succession of the seasurface microlayer in the coastal Baltic Sea under natural and experimentally induced low-wind conditions. Biogeosciences 7, 2975-2988. doi: 10.5194/bg-72975-2010

Sun, C., Sperling, M., and Engel, A. (2018). Effect of wind speed on the size distribution of biogenic gel particles in the sea surface microlayer: insights from a wind wave channel experiment. Biogeosciences 15, 3577-3589. doi: 10.5194/ bg-15-3577-2018

Taylor, J. D., Cottingham, S. D., Billinge, J., and Cunliffe, M. (2014). Seasonal microbial community dynamics correlate with phytoplankton-derived polysaccharides in surface coastal waters. ISME J. 8, 245-248. doi: 10.1038/ ismej.2013.178

Taylor, J. D., and Cunliffe, M. (2014). High-throughput sequencing reveals neustonic and planktonic microbial eukaryote diversity in coastal waters. J. Phycol. 50, 960-965. doi: 10.1111/jpy.12228

Taylor, J. D., and Cunliffe, M. (2017). Coastal bacterioplankton community response to diatom-derived polysaccharide microgels. Environ. Microbiol. Rep. 9, 151-157. doi: 10.1111/1758-2229.12513

Teeling, H., Fuchs, B. M., Bennke, C. M., Krüger, K., Chafee, M., Kappelmann, L., et al. (2016). Recurring patterns in bacterioplankton dynamics during coastal spring algae blooms. eLife 5:e11888. doi: 10.7554/eLife.1 1888

Wietz, M., Wemheuer, B., Simon, H., Giebel, H. A., Seibt, M. A., Daniel, R., et al. (2015). Bacterial community dynamics during polysaccharide degradation at contrasting sites in the Southern and Atlantic Oceans. Environ. Microbiol. 17, 3822-3831. doi: 10.1111/1462-2920.12842

World Health Organization (1995). The Sea-Surface Microlayer and Its Role in Global Change. Geneva: WHO.

Wurl, O., and Holmes, M. (2008). The gelatinous nature of the sea-surface microlayer. Mar. Chem. 110, 89-97. doi: 10.1016/j.marchem.2008.02.009 
Wurl, O., Miller, L., and Vagle, S. (2011). Production and fate of transparent exopolymer particles in the ocean. J. Geophys. Res. Ocean 116:C00H13. doi: 10.1029/2011JC007342

Zäncker, B., Bracher, A., Röttgers, R., and Engel, A. (2017). Variations of the organic matter composition in the sea surface microlayer: a comparison between open ocean, coastal, and upwelling sites off the Peruvian coast. Front. Microbiol. 8:2369. doi: 10.3389/fmicb.2017.02369

Zhang, Z., Liu, L., Liu, C., and Cai, W. (2003). Studies on the sea surface microlayer: II. The layer of sudden change of physical and chemical properties. J. Colloid Interface Sci. 264, 148-159. doi: 10.1016/S0021-9797(03)00390-4

Zhou, J., Bruns, M. A., and Tiedje, J. M. (1996). DNA recovery from soils of diverse composition. Appl. Environ. Microbiol. 62, 316-322.

Zhou, J., Mopper, K., and Passow, U. (1998). The role of surface-active carbohydrates in the formation of transparent exopolymer particles by bubble adsorption of seawater. Limnol. Oceanogr. 43, 1860-1871. doi: 10.4319/lo.1998. 43.8.1860

Conflict of Interest Statement: The authors declare that the research was conducted in the absence of any commercial or financial relationships that could be construed as a potential conflict of interest.

Copyright (c) 2018 Zäncker, Cunliffe and Engel. This is an open-access article distributed under the terms of the Creative Commons Attribution License (CC BY). The use, distribution or reproduction in other forums is permitted, provided the original author(s) and the copyright owner(s) are credited and that the original publication in this journal is cited, in accordance with accepted academic practice. No use, distribution or reproduction is permitted which does not comply with these terms. 